\title{
Genotoxic potential of diesel exhaust particles from the combustion of first- and second-generation biodiesel fuels - the FuelHealth project
}

\author{
Magdalena Kowalska ${ }^{1}$ - Aneta Wegierek-Ciuk ${ }^{1}$ - Kamil Brzoska ${ }^{2}$. \\ Maria Wojewodzka ${ }^{2}$ • Sylwia Meczynska-Wielgosz ${ }^{2}$. Joanna Gromadzka-Ostrowska ${ }^{3}$. \\ ${\text { Remigiusz } \text { Mruk }^{4} \text { - Johan Øvrevik }}^{5}$ - Marcin Kruszewski ${ }^{2,6,7}$ - Anna Lankoff ${ }^{1,2}$
}

Received: 3 April 2017 / Accepted: 22 August 2017 / Published online: 9 September 2017

(C) The Author(s) 2017. This article is an open access publication

\begin{abstract}
Epidemiological data indicate that exposure to diesel exhaust particles (DEPs) from traffic emissions is associated with higher risk of morbidity and mortality related to cardiovascular and pulmonary diseases, accelerated progression of atherosclerotic plaques, and possible lung cancer. While the impact of DEPs from combustion of fossil diesel fuel on human health has been extensively studied, current knowledge of DEPs from combustion of biofuels provides limited and inconsistent information about its mutagenicity and genotoxicity, as well as possible adverse health risks. The objective of the present work was to compare the genotoxicity of DEPs from combustion of two first-generation fuels, $7 \%$ fatty acid methyl esters (FAME) (B7) and 20\% FAME (B20), and a second-generation 20\% FAME/hydrotreated vegetable oil (SHB: synthetic hydrocarbon biofuel) fuel. Our results revealed that particulate engine emissions from each type of biodiesel fuel induced genotoxic effects in BEAS-2B and A549 cells, manifested as the in-
\end{abstract}

Responsible editor: Philippe Garrigues

Electronic supplementary material The online version of this article (https://doi.org/10.1007/s11356-017-9995-0) contains supplementary material, which is available to authorized users.

Anna Lankoff

alankoff@gmail.com

1 Department of Radiobiology and Immunology, Institute of Biology, Jan Kochanowski University, 15 Swietokrzyska Str, 25-406 Kielce, Poland

2 Center for Radiobiology and Biological Dosimetry, Institute of Nuclear Chemistry and Technology, 16 Dorodna Str, 03-195 Warsaw, Poland

3 Faculty of Human Nutrition and Consumer Science, Warsaw University of Life Sciences, 166 Nowoursynowska Str, 02-787 Warsaw, Poland creased levels of single-strand breaks, the increased frequencies of micronuclei, or the deregulated expression of genes involved in DNA damage signaling pathways. We also found that none of the tested DEPs showed the induction of oxidative DNA damage and the gamma-H2AX-detectable double-strand breaks. The most pronounced differences concerning the tested particles were observed for the induction of single-strand breaks, with the greatest genotoxicity being associated with the B7-derived DEPs. The differences in other effects between DEPs from the different biodiesel blend percentage and biodiesel feedstock were also observed, but the magnitude of these variations was limited.

Keywords Diesel exhaust particles $\cdot$ First- and second-generation biodiesel fuels $\cdot$ Single- and double-strand breaks $\cdot$ Oxidative DNA damage $\cdot$ Chromosomal damage
4 Faculty of Production Engineering, Warsaw University of Life Sciences, 166 Nowoursynowska Str, 02-787 Warsaw, Poland

5 Domain of Infection Control and Environmental Health, Norwegian Institute of Public Health, P.O. Box 4404, Nydalen, 0403 Oslo, Norway

6 Department of Molecular Biology and Translational Research, Institute of Rural Health, Jaczewskiego 2, 20-090 Lublin, Poland

Faculty of Medicine, University of Information Technology and Management in Rzeszow, Sucharskiego 2, 35-225 Rzeszow, Poland 


\section{Introduction}

The overall impact of engine emissions on human health has been studied for a long time, mostly due to the presence of polycyclic aromatic hydrocarbons (PAHs) and their derivatives (nitro-PAHs) in diesel exhaust particles (DEPs). Epidemiological data indicate that exposure to DEPs from traffic emissions is associated with a higher risk of morbidity and mortality related to cardiovascular and pulmonary diseases (Vieira et al. 2017; Steiner et al. 2016). There is also compelling evidence from animal experimental models and humans that exposure to DEPs and ambient air particles is associated with accelerated progression of atherosclerotic plaques (Cao et al. 2016). Recently, evidence has also been obtained about their possible carcinogenicity (Hesterberg et al. 2012). While the impact of DEPs from combustion of fossil diesel fuel on human health has been extensively studied, current knowledge of DEPs from combustion of biodiesels provides limited and inconsistent information about their mutagenicity and genotoxicity, as well as possible adverse health risks. The vast majority of studies comparing DEPs from combustion of fossil diesels and biodiesels used the bacterial reverse mutation assay (so-called Ames test). Early research on mutagenicity of DEPs in Salmonella typhimurium tester strains TA98 (frame-shift mutation) and TA100 (base-pair substitution) has shown that biodiesel emissions induced subtly lower mutagenic potency when compared to the exhaust of fossil fuels (Bünger et al. 1998; Westerholm et al. 2001). Other studies revealed either no differences or significant increase in mutagenic activity of biodiesel emission extracts (Westphal et al. 2012; Krahl et al. 2008). The more recent studies revealed a clear reduction of mutagenic effects, showing less differences between the biodiesels compared to reference fuels (Bünger et al. 2012). It is believed that the main contributors to the mutagenicity of biodiesel DEPs are the $\mathrm{PAH}$ and nitro-PAH compounds adsorbed onto the particle surface. Besides the mutagenicity determined in a prokaryote model, genotoxic properties of biodiesel-derived DEPs have also been evaluated in eukaryote models. Two studies dealing with the formation of bulky DNA adducts have shown contradictory results. Ross et al. (2015) reported the formation of multiple DNA adducts by the in vitro metabolic activation of organic extracts of DEPs from combustion of fossil diesel and soy biodiesel. However, no formation of DNA adducts was presented in vitro by André et al. (2015), even if cells were fully able to metabolize nitroaromatics and PAHs. Other in vitro studies revealed the induction of DNA strand breaks, but either no differences or significant differences were observed between DEPs from combustion of fossil diesel and biodiesel (Jalava et al. 2010; Hemmingsen et al. 2011; Jalava et al. 2012). Similarly, inconsistent results were observed for the induction of micronuclei by DEPs from combustion of fossil diesel and biodiesel, showing either no difference or significant increase of chromosomal DNA damage by biodiesel-derived DEPs (Leme et al. 2012; Cervena et al. 2016). In summary, these contradictory trends are hard to interpret and may be caused by chance in light of relatively limited data. Moreover, a comparison of the results of different toxicological studies for exhaust particles produced by biodiesel combustion is difficult because of differences in the experimental approach, including age and type of diesel engine, drive cycle, feedstock blend, and its percentage in the blended fuel. The objective of the present work was to compare the genotoxicity of different DEPs from combustion of first- and second-generation biodiesel fuels in relation to their physicochemical properties. DEPs were produced by the $1.3 \mathrm{JTD}$ engine (Euro V stage), fueled with three biodiesel fuels of commercial interest: the first-generation B7 biodiesel fuel (7\% fatty acid methyl esters (FAME)), which is currently used in the EU; the first-generation B20 biodiesel fuel (20\% FAME); and the second-generation (synthetic hydrocarbon biofuel (SHB)) biodiesel fuel (7\% FAME and 13\% synthetic hydrotreated vegetable oil (HVO)). These biodiesel fuels were combusted under identical engine operation conditions, and emissions were evaluated during a certified test cycle. Detailed physicochemical characterizations of DEPs were performed to investigate how the composition of three types of DEPs affects their biological effects in vitro, measured as induction of single- and double-strand breaks, oxidative DNA damage, and chromosomal damage. In addition, the expression of genes involved in DNA damage signaling was also evaluated to screen for possible molecular mechanisms of toxicity.

\section{Materials and methods}

\section{Collection of DEPs}

A Fiat Panda with compression ignition engine 1.3 JTD (common rail third-generation injection system, engine capacity $1248 \mathrm{~cm}^{3}$, max power $75 \mathrm{bhp}$, max torque $190 \mathrm{Nm}$, production year 2014), fulfilling the requirements of the Euro V stage, was used as a DEP source. The engine was tested under controlled conditions on a chassis dynamometer (Schenck Komeg EMDY 48 ) at constant engine speed and load of $340 \mathrm{rpm}$ and $45.7 \%$, respectively, corresponding to a constant vehicle speed of $43.75 \mathrm{~km} / \mathrm{h}$. The engine temperature was kept at $94{ }^{\circ} \mathrm{C}$ during the test cycle. The engine was fueled by three different mixtures of diesel oil and biocomponents: (1) first-generation biodiesel fuel "B7," containing 7\% vol. FAME in diesel oil; (2) firstgeneration biodiesel fuel "B20," containing 20\% vol. FAME in diesel oil; and (3) second-generation biodiesel fuel "SHB," containing 13\% vol. synthetic HVO (NExBTL) and 7\% vol. FAME in diesel oil. According to the newest EU Directive 2015/1513 that encourages the use of second-generation biofuels (such as HVO), instead of first-generation biofuels 
(such as FAME and Rapeseed oil methyl ester (RME)), we chosen these two types of biofuels: HVO which is Neste Renewable biodiesel (formerly NEXBTL), produced in a patented vegetable oil refining process and commercialized by the Finnish oil and refining company Neste (Rantanen et al. 2005) and FAME, which is currently used in EU and produced in the process of transesterification of plant oils with methanol by ORLEN Poland. The DEPs used in the present study were collected from the main diesel exhaust without a diesel particle filter on PTFE-coated glass fiber filters (Pallflex, Emfab filters, TX40HI20WW, $70 \mathrm{~mm}$ ). For the quantitative analysis, the blank sampling filters were marked and weighed. The filters from individual fuels were separately re-weighed after sampling, and the mass differences before and after the sampling were compared and analyzed to determine the total particulate matter collected. Driving cycles and particulate collections were repeated with the same fuel several times to new filter sets to ensure that a sufficiently large sample mass would be obtained in order to complete the toxicological and chemical analyses. Filters were stored in the freezer at $-20{ }^{\circ} \mathrm{C}$ for 1 week before analysis. Particles for in vitro experiments were scraped from the filters using a clean stainless steel blade.

\section{Preparation of diesel exhaust particles}

DEP-stock solutions were prepared by dispersion of $2 \mathrm{mg}$ of particles in $1 \mathrm{~mL}$ of LHC-9 serum-free medium (for experiments with BEAS-2B cells) or in $1 \mathrm{~mL}$ of F12 Ham medium supplemented with $10 \%$ FCS (for experiments with A549 cells). DEP-dispersions were then sonicated on ice using the Sonic Vibra Cell ultrasonic liquid processor (USA). Ultrasonic energy $(3 \mathrm{~kJ})$ was provided in pulses $(30 \mathrm{~s}$ on, $10 \mathrm{~s}$ off) at $60 \%$ amplitude. Stock solutions were dispensed $(100 \mu \mathrm{L})$ into sterile $1-\mathrm{mL}$ cryogenic vials and stored at $-20^{\circ} \mathrm{C}$. The samples were thawed before each set of experiments at $37^{\circ} \mathrm{C}$ for $60 \mathrm{~s}$, dispersed in the corresponding medium at a ratio of 1:10, and mixed prior to use (working solution).

\section{Physicochemical characterization of diesel exhaust particles}

Physicochemical characterization of diesel exhaust particles was described in detail by Lankoff et al. (2017). Briefly, sample size distribution was measured by the Nanoparticle Tracking Analysis (NTA) with a NanoSight LM20 (NanoSight, Amesbury, UK), equipped with a sample chamber with a 640-nm laser. Zeta potential and polydispersity index were determined by DLS method at $25^{\circ} \mathrm{C}$ in a folded capillary cell at $150 \mathrm{~V}$ and M3-PALS detection using noninvasive backscatter at $173^{\circ}$ with an Avalanche photodiode, Q.E. > 50\% at $633 \mathrm{~nm}$ (Malvern, Malvern Hills, UK). The shape of DEPs was analyzed by transmission electron microscopy (TEM) (JEOL 1200 EXII, JEOL, JAPAN) operating at an acceleration voltage of $120 \mathrm{kV}$. Elemental analysis of DEPs was performed by digital scanning electron microscopy (SEM) type DSM 942 (Zeiss, Germany) in the secondary electron (SE) mode using the energy dispersive X-ray spectrometry (EDS) with Quantax 400 (Bruker, Germany) system. Separation and analysis of PAHs from particulate extracts were described in detail by Czarnocka and Odziemkowska (2016). The content of 17 PAHs was measured by the Agilent 7890A GC System chromatograph coupled with a mass spectrometer MS 5975C using a low-polarity Rtx-5ms capillary column $(30 \mathrm{~m} \times 0.25 \mathrm{~mm} \times 0.25 \mu \mathrm{m})$ (Restek, Bellefonte, PA, USA).

\section{Cell cultures}

The human type-II-like alveolar epithelial cell line A549 and the human bronchial epithelial cell line BEAS-2B were purchased from the American Type Tissue Culture Collection (ATCC, Rockville, MD) and maintained according to ATCC protocols. Briefly, A549 were cultured in F12 Ham medium supplemented with $10 \%$ FCS and $2 \mathrm{mM}$ L-glutamine, whereas BEAS-2B were cultured in LHC-9 serum-free bronchial epithelial growth medium on non-coated plates. Both cell lines were maintained in an incubator at $37{ }^{\circ} \mathrm{C}$ with $5 \%$ $\mathrm{CO}_{2}$. The exponentially growing BEAS-2B and A549 cells were incubated with $1,10,25$, and $50 \mu \mathrm{g} / \mathrm{mL}$ of DEPs for 6 , 24 , or $48 \mathrm{~h}$ (depending on the assay procedure). The doses and treatment times were chosen based on the cytotoxicity results (e.g., induction of apoptosis and necrosis, inhibition of protein synthesis, generation of free radicals), published previously by our group (Lankoff et al. 2017).

\section{Determination of single-strand DNA breaks and oxidative DNA damage by the comet assay}

The exponentially growing BEAS-2B and A549 cells were incubated with $1,10,25$, and $50 \mu \mathrm{g} / \mathrm{mL}$ of DEPs for $24 \mathrm{~h}$. Positive control cells were irradiated with a dose of 2 Gy of Xrays at a dose rate of $1.14 \mathrm{~Gy} / \mathrm{min}$ (Xylon International Smart 200-E irradiator, Xylon, San Jose, CA). The comet assay (single cell gel electrophoresis) was performed as previously described (Wojewódzka et al. 1998). Briefly, an aliquot of cell suspension was mixed with an equal volume of $2 \%$ low melting point agarose (type VII, Sigma), put on a microscope slide pre-coated with $0.5 \%$ regular agarose (type I-A, Sigma), and left on ice. After agarose solidification, the slides were immersed in a cold lysing solution $(2.5 \mathrm{M} \mathrm{NaCl}, 100 \mathrm{mM}$ $\mathrm{Na}_{2}$ EDTA, $10 \mathrm{mM}$ Tris, and $1 \%$ Triton $\mathrm{X}-100, \mathrm{pH} 10$ ) or left for $30 \mathrm{~min}$ in culture media at $37{ }^{\circ} \mathrm{C}$ to allow damage repair. After 40 min lysis, the slides were placed on a horizontal gel electrophoresis unit filled with fresh electrophoretic buffer (1 mM Na2EDTA (sodium ethylenediamine tetraacetate) 
and $300 \mathrm{mM} \mathrm{NaOH}$ ) and allowed to stay in this buffer for 40 min for DNA unwinding. Next, electrophoresis was performed $\left(1.2 \mathrm{~V} / \mathrm{cm}, 30 \mathrm{~min}, 10^{\circ} \mathrm{C}\right)$. After electrophoresis, the slides were washed with $0.4 \mathrm{M}$ Tris, $\mathrm{pH} 7.5(3 \times 5 \mathrm{~min})$, and stained with DAPI (4',6-diamidino-2-fenylindole), $50 \mu \mathrm{L}$ ( $1 \mu \mathrm{g} / \mathrm{mL}$ ). Basically, the same test was applied for the measurement of DNA base damage. Incubation of irradiated cells with the formamidopyrimidine glycosylase (FPG), BioLabs, was carried out as previously described (Kruszewski et al. 1998). Briefly, after lysis, the slides were washed $3 \times 5 \mathrm{~min}$ with the buffer $(40 \mathrm{mM}$ Hepes (4-(2-hydroxyethyl)-1-piperazineethanesulfonic acid), $0.1 \mathrm{M} \mathrm{KCl}, 0.5 \mathrm{mM}$ EDTA, $0.2 \mathrm{mg} / \mathrm{mL}$ bovine serum albumin, $\mathrm{pH} 8$ ) at $4{ }^{\circ} \mathrm{C}$. Further, $50 \mu \mathrm{L}$ of FPG solution $(4.8 \times 10-2 \mathrm{U})$ in the buffer was placed on each slide, covered with cover glass, and incubated for $30 \mathrm{~min}$ in a light-protected box at $37^{\circ} \mathrm{C}$. Slides were stained with DAPI $(1 \mu \mathrm{g} / \mathrm{mL})$ and analyzed as described above. Image analysis of data was performed by the Comet Assay IV image analysis system (Perceptive Instruments, UK). Data for 75 randomly selected comets per point were analyzed. Percent of DNA in comet's tail was chosen as a measure of DNA damage.

\section{Analysis of double-strand DNA breaks by the $\gamma-\mathrm{H} 2 \mathrm{AX}$ assay}

BEAS-2B and A549 cells at exponential growth were incubated with $1,10,25,50$, and $100 \mu \mathrm{g} / \mathrm{mL}$ of the different DEPs for $24 \mathrm{~h}$. Positive control cells were irradiated with a dose of $2 \mathrm{~Gy}$ of X-rays at a dose rate of $1.14 \mathrm{~Gy} / \mathrm{min}$ (Xylon International Smart 200-E irradiator, Xylon, San Jose, CA). $\gamma$-H2AX foci were detected with the $\gamma$-H2AX (H2A.X PHOS) Detection Kit (Upstate Biotechnology, USA). Briefly, after incubation, the cells were washed, fixed, and resuspended in a permeabilization solution (0.5\% saponin, $10 \mathrm{mM}$ HEPES, $140 \mathrm{mM}$ $\mathrm{NaCl}, 2.5 \mathrm{mM} \mathrm{CaCl} 2)$. Unspecific binding was blocked for $1 \mathrm{~h}$ in blocking buffer BSA-T-PBS (1\% BSA, 0.1\% Triton X-100 in PBS). Thereafter, the cells were suspended in BSA-T-PBS containing $2 \mu \mathrm{g}$ of the fluorescein-conjugated $\gamma-\mathrm{H} 2 \mathrm{AX}$ antibody (monoclonal anti-phosphohistone H2AX antibody, Upstate Biotechnology) for $20 \mathrm{~min}$. Cells were analyzed with a FACScan (Becton Dickinson, San Jose, CA, USA). Twenty thousand cells per point were analyzed for $\gamma-\mathrm{H} 2 \mathrm{AX}$ intensity.

\section{Determination of chromosomal DNA damage by the micronucleus assay}

The exponentially growing BEAS-2B and A549 cells were incubated with $1,10,25$, and $50 \mu \mathrm{g} / \mathrm{mL}$ of DEPs for 24 and $48 \mathrm{~h}$. Positive control cells were irradiated with a dose of $2 \mathrm{~Gy}$ of X-rays at a dose rate of $1.14 \mathrm{~Gy} / \mathrm{min}$ (Xylon International Smart 200-E irradiator, Xylon, San Jose, CA). After $1 \mathrm{~h}$ of treatment, cytochalasin-B (final concentration of $10 \mu \mathrm{g} / \mathrm{mL}$ ) was added into the cell culture medium in order to block cytokinesis and obtain binucleated cells. Cytochalasin-B is an inhibitor of microfilament ring assembly required for the completion of cytokinesis. This inhibition allows to generate once-divided binucleated cells, which are the cells that can express micronuclei. Restricting scoring of micronuclei in binucleated cells prevents confounding effects caused by suboptimal or altered cell division kinetics, which is a major variable in the micronucleus assay protocol that does not distinguish between non-dividing cells that cannot express micronuclei and dividing cells that can (Fenech 2007). After the exposure, the cells were harvested by centrifugation and subjected to cold mild hypotonic treatment $(0.075 \mathrm{M} \mathrm{KCl})$ for $8 \mathrm{~min}$, fixed twice with methanol/acetic acid/ringer solution (13:12:3), and then dropped on clean, dry slides. The cells were mounted and stained in the Vectashield Mounting Medium containing DAPI (4',6-diamidyno-2-fenyloindol). The slides were coded, and the frequency of micronuclei (MN) in 3000 binucleated cells (BNC) per dose (1000 cells/ replicate) was analyzed with the fully automated image acquisition and analysis system Metafer (Metasystems, Germany) by one skilled scorer. The frequency of $\mathrm{MN}$ in untreated controls and positive controls (2 Gy) was also scored in 3000 BNC (1000 cells/replicate), according to the criteria proposed by Fenech (2007).

\section{RNA isolation, reverse transcription, and real-time PCR}

Total RNA was extracted from cell pellets using the RNeasy Mini Kit (Qiagen) according to manufacturer's protocol. To assess the concentration and purity of RNA, the portion of every RNA sample was diluted in TE buffer ( $\mathrm{pH}$ 8.0) and the absorbance at 230, 260, and $280 \mathrm{~nm}$ was measured using Cary 50 UV-Vis spectrophotometer (Varian). All RNA samples used in subsequent analyses had a concentration $\geq 100 \mathrm{ng} / \mu \mathrm{L}$, as well as A260/A280 and A260/A230 ratios $\geq 2.0$. RNA integrity was tested by agarose gel electrophoresis. For PCR array analysis, $1 \mu \mathrm{g}$ of total RNA was converted to complementary DNA (cDNA) in a $20-\mu \mathrm{L}$ reaction volume using RT $^{2}$ First Strand Kit (Qiagen). The cDNA was diluted with $91 \mu$ distilled water and used for the expression profiling using the human DNA damage signaling pathway PCR array (Qiagen, cat. no. PAHS-029Z) according to manufacturer's instructions. Briefly, a total volume of $25 \mu \mathrm{L}$ of PCR reaction mixture, which included $12.5 \mu \mathrm{L}$ of $\mathrm{RT}^{2} \mathrm{SYBR}$ Green/ROX qPCR Master Mix from Qiagen (containing HotStart DNA Taq polymerase, SYBR Green dye and the ROX reference dye), $11.5 \mu \mathrm{L}$ of double-distilled $\mathrm{H}_{2} \mathrm{O}$, and $1 \mu \mathrm{L}$ of diluted template cDNA, was used for each primer set in each well of the PCR array. One technical replicate was performed for each sample. PCR amplification was carried out using 7500 Real-Time PCR System (ThermoFisher Scientific) with an initial 10 -min step at $95{ }^{\circ} \mathrm{C}$ followed by 
40 cycles of $95^{\circ} \mathrm{C}$ for $15 \mathrm{~s}$ and $60^{\circ} \mathrm{C}$ for $1 \mathrm{~min}$. Relative gene expression was calculated using the $\Delta \Delta \mathrm{Ct}$ method with ACTB, B2M, GAPDH, HPRT1, and RPLP0 as reference controls. Calculations were done using the Relative Quantification Software version 3.2.1-PRC-build1 (Thermo Fisher Cloud). Statistical differences were examined by Student's $t$ test with $p<0.05$ considered to be statistically significant.

\section{Statistical evaluation}

Statistical analysis of the obtained data was performed using the Statistica 7.1 software (Stat Soft. Inc., Tulsa, USA). The data were expressed as mean \pm standard deviation (SD) of at least three independent experiments. Data were evaluated by Kruskal-Wallis one way analysis of variance on ranks (ANOVA) followed by the post hoc Fisher's test. Correlation coefficients between the obtained data were evaluated by the Pearson product-moment. Differences were considered statistically significant when the $p$ value was less than $<0.05$.

\section{Results}

\section{Physicochemical characterization of DEPs}

A detailed physicochemical characterization of the DEPs used in this study has previously been published (Lankoff et al. 2017. As shown in Table 1, the average hydrodynamic diameters of all three types of DEPs were comparable, if the same culture medium was used. However, the B7 biofuel generated the lowest number of particles with diameter in the range 1-90 $\mathrm{nm}(\sim 55 \%)$, as compared with the B20 biofuel $(\sim 70 \%)$ and the SHB biofuel $(\sim 85 \%)$. The polydispersity index values for all DEPs were less than 0.5 , indicating high homogeneity of the suspension. The zeta potentials were negative and comparable for all tested DEPs, indicating stability of the colloidal system. TEM analysis revealed that all three types of DEPs were nearly spherical, and the particles were present as single particles, clusters, or chain-like aggregates. All DEPs were composed primarily of carbon $(\sim 85 \%)$. The next most abundant elements were oxygen and nitrogen. Zinc was present in all DEPs at low concentration. Concentrations of sulfur, copper, and chlorine were below $0.5 \%$ in all samples, with the exception of chlorine in SHB-DEP, which was slightly above $1 \%$. Silver and iron could only be detected in SHB-DEP samples. The content of PAHs in DEP-derived organic extracts was the highest in the B7-DEP sample $(165.78 \mathrm{ng} / \mathrm{mg})$ and the lowest in the SHB-DEPs sample $(69.93 \mathrm{ng} / \mathrm{mg})$. The data showed that pyrene, fluoranthene, phenanthrene, and chrysene were the most abundant PAHs in all samples.
Table 1 Physicochemical characteristics of diesel exhaust particles from the combustion of B7, B20, and SHB biodiesel fuels. Elemental composition of DEPs (wt\%), PAHs (ng/mg) in the organic extracts from DEPs, particle size $(\mathrm{nm})$, polydispersity index, and zeta potential $(\mathrm{mV})$ of B7-DEPs, B20-DEPs, and SHB-DEPs in cell culture medium F12+FBS or LHC-9. All data presented as mean of triplicates \pm SD

Chemical constituents of Diesel exhaust particles the particulate samples

B7-DEP B20-DEP SHB-DEP

Elemental composition (wt \%)

\begin{tabular}{|c|c|c|c|}
\hline \\
\hline Carbon & $85.53 \pm 0.93$ & $86.76 \pm 1.09$ & $87.51 \pm 0.86$ \\
\hline Oxygen & $7.51 \pm 1.02$ & $6.31 \pm 1.21$ & $2.24 \pm 0.85$ \\
\hline Nitrogen & $5.12 \pm 0.97$ & $5.15 \pm 0.87$ & $5.11 \pm 0.85$ \\
\hline Zinc & $1.40 \pm 0.44$ & $1.24 \pm 0.05$ & $2.25 \pm 0.77$ \\
\hline Sulfur & $0.22 \pm 0.04$ & $0.22 \pm 0.04$ & $0.26 \pm 0.07$ \\
\hline Copper & $0.18 \pm 0.03$ & $0.19 \pm 0.08$ & $0.45 \pm 0.21$ \\
\hline Chlorine & $0.04 \pm 0.01$ & $0.10 \pm 0.02$ & $1.33 \pm 0.36$ \\
\hline Silver & - & - & $0.72 \pm 0.12$ \\
\hline Iron & - & - & $0.21 \pm 0.03$ \\
\hline \multicolumn{4}{|l|}{ Organic components (ng/mg) } \\
\hline Naphthalene & 3.86 & 7.74 & 3.13 \\
\hline Acenaphthylene & 0.26 & 0.92 & 0.14 \\
\hline Acenaphthalene & 0.11 & 0.19 & 0.07 \\
\hline Fluorine & 0.56 & 1.41 & 0.23 \\
\hline Phenanthrene & 12.33 & 20.83 & 5.13 \\
\hline Anthracene & 1.13 & 1.73 & 0.56 \\
\hline Fluoranthene & 36.04 & 6.06 & 6.36 \\
\hline Pyrene & 90.33 & 43.23 & 40.53 \\
\hline Benzo(a)anthracene & 2.07 & 1.14 & 1.76 \\
\hline Chrysene & 10.26 & 3.98 & 6.92 \\
\hline Benzo(b)fluoranthene & 4.30 & 1.65 & 2.80 \\
\hline Benzo(k)fluoranthene & 2.59 & 1.58 & 1.38 \\
\hline Benzo(a)pyrene & 0.38 & 0.83 & 0.22 \\
\hline Benzo(a)fluoranthene & 0.65 & 1.57 & 0.27 \\
\hline Indeno(1,2,3-c,d)pyrene & 0.36 & 0.44 & 0.19 \\
\hline Dibenzo(a,h)anthracene & 0.07 & 0.24 & 0.05 \\
\hline Dibenzo(g,h,i)perylene & 0.47 & 0.33 & 0.20 \\
\hline Total PAHs & 165.78 & 93.54 & 69.93 \\
\hline Hydrodynamic & $78 \pm 55^{\mathrm{a}}$ & $80 \pm 43^{\mathrm{a}}$ & $68 \pm 37^{\mathrm{a}}$ \\
\hline diameter $(\mathrm{nm})$ & $126 \pm 64^{b}$ & $107 \pm 49^{\mathrm{b}}$ & $113 \pm 48^{\mathrm{b}}$ \\
\hline Polydispersity index & $0.185 \pm 0.02^{\mathrm{a}}$ & $0.455 \pm 0.05^{\mathrm{a}}$ & $0.334 \pm 0.06^{\mathrm{a}}$ \\
\hline & $0.190 \pm 0.01^{\mathrm{b}}$ & $0.470 \pm 0.08^{\mathrm{b}}$ & $0.383 \pm 0.02^{\mathrm{b}}$ \\
\hline otential (mV) & $-22.4 \pm 3.22^{\mathrm{a}}$ & $-20.1 \pm 1.98^{\mathrm{a}}$ & $-23.5 \pm 3.03^{\mathrm{a}}$ \\
\hline & $-21.5 \pm 2.31^{\mathrm{b}}$ & $-19.93 \pm 3.98^{b}$ & $-22.1 \pm 2.98^{\mathrm{b}}$ \\
\hline
\end{tabular}

${ }^{\mathrm{a}} \mathrm{F} 12+\mathrm{FBS}$

${ }^{\mathrm{b}}$ LHC-9

\section{DEPs induce single-strand breaks but not oxidative DNA damage in BEAS-2B and A549 cells}

BEAS-2B and A549 cells were cultured in the presence of three types of DEPs $(1,10,25$, and $50 \mu \mathrm{g} / \mathrm{mL})$ for $24 \mathrm{~h}$. DEPs induced DNA damage in BEAS-2B cells versus corresponding control cultures as shown in Fig. 1. The increased level of single-strand DNA breaks (SSBs) was observed in cells incubated with 10,25 , and $50 \mu \mathrm{g} / \mathrm{mL}$ of B7-DEP $(p=0.0003$, 

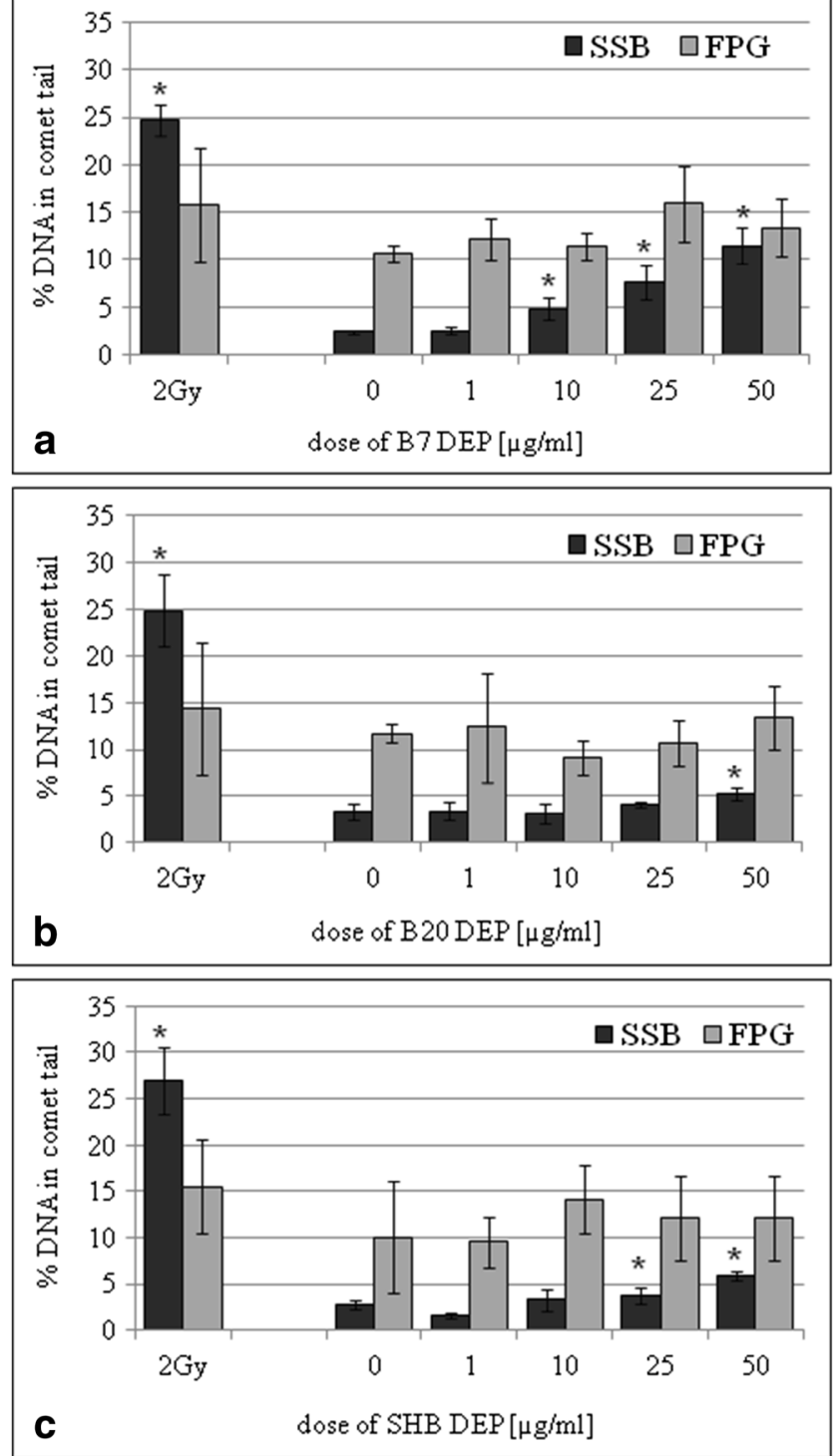

Fig. 1 Effect of DEPs on induction of single-strand breaks (SSBs) and oxidative DNA damage (FPG) in BEAS-2B cells. DNA damage was determined by the comet assay. a B7-derived DEPs, b B20-derived DEPs, and $\mathbf{c}$ SHB-derived DEPs. Data are expressed as means \pm S.D. from three independent experiments. $p<0.05$. Asterisk denotes statistically significant difference versus corresponding control group

$p=0.0001$, and $p=0.0001$, respectively) (Fig. 1a), in cells incubated with $50 \mu \mathrm{g} / \mathrm{mL}$ of B20-DEP $(p=0.0036)$ (Fig. 1b), and in cells incubated with 25 and $50 \mu \mathrm{g} / \mathrm{mL}$ of SHB-DEP ( $p=0.0002, p=0.0001$, respectively). None of the tested DEPs showed significant induction of oxidative DNA damage in BEAS-2B. The effect of DEPs on induction of DNA damage in A549 cells is shown in Fig. 2. The increased level of SSBs was observed in cells incubated with 10,25 , and $50 \mu \mathrm{g} / \mathrm{mL}$ of B7-DEP ( $p=0.0018, p=0.0001$, and $p=0.0001$, respectively) (Fig. 2a); 25 and $50 \mu \mathrm{g} / \mathrm{mL}$ of B20-DEP ( $p=0.0383$ and $p=0.0001$, respectively) (Fig. 2b); and in cells incubated with 10,25 , and $50 \mu \mathrm{g} / \mathrm{mL}$ of SHB-DEP ( $p=0.0301, p=0.0010$ and $p=0.0001$, respectively) (Fig. 2c). None of the tested DEPs
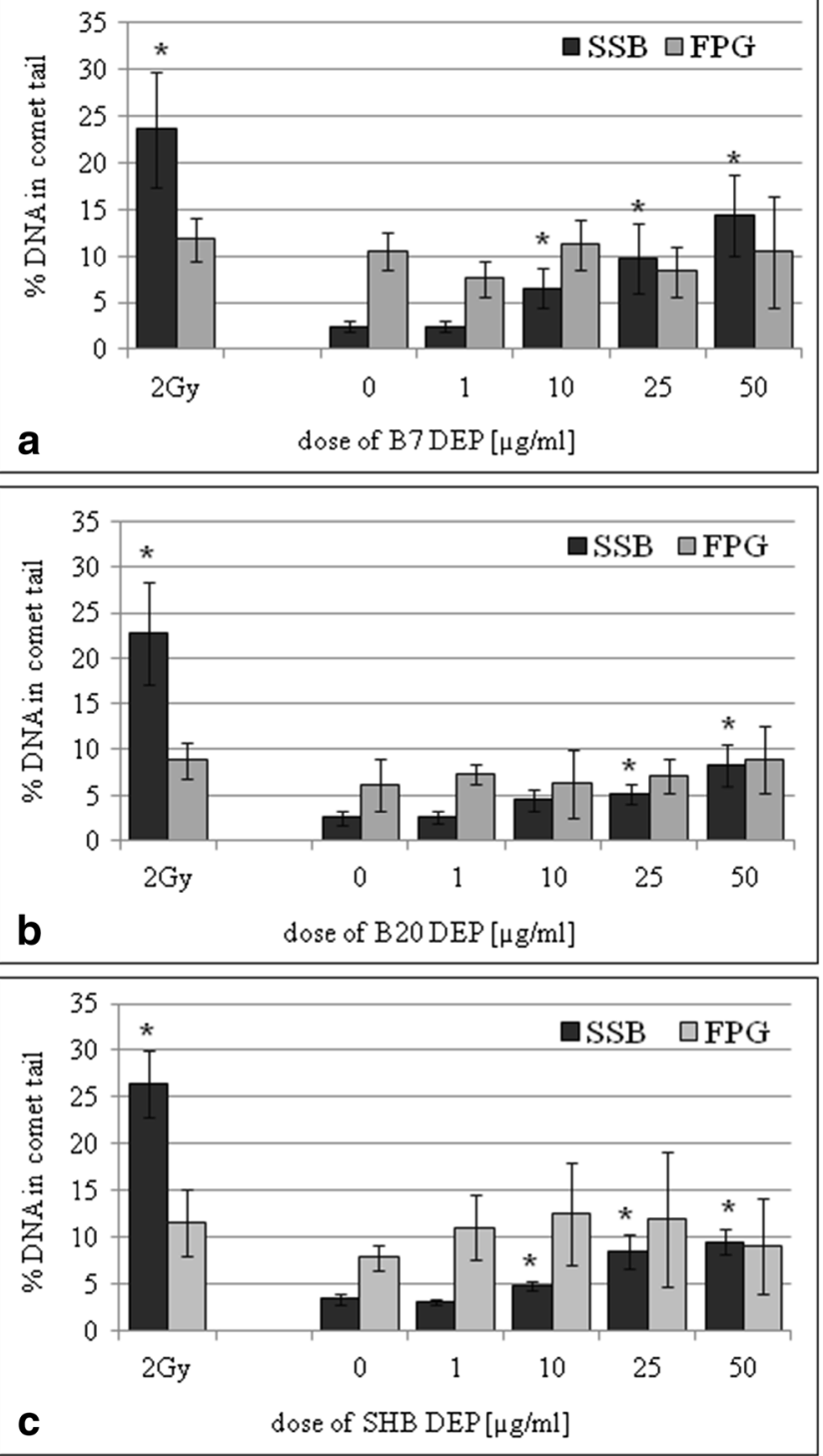

Fig. 2 Effect of DEPs on induction of single-strand breaks (SSBs) and oxidative DNA damage (FPG) in A549 cells. DNA damage was determined by the comet assay. a B7-derived DEPs, b B20-derived DEPs, and c SHB-derived DEPs. Data are expressed as means \pm S.D. from three independent experiments. $p<0.05$. Asterisk denotes statistically significant difference versus corresponding control group

showed significant induction of oxidative DNA damage in A549 cells. B7-DEP were the most effective in inducing SSBs in BEAS-2B $(p=0.0001$ for B7-DEP vs B20-DEP, $p=0.0001$ for B7-DEP vs SHB-DEP, $p=0.2256$ for $\mathrm{B} 20$ DEP vs SHB-DEP) and A549 cells ( $p=0.0019$ for B7-DEP vs B20-DEP, $p=0.0232$ for B7-DEP vs SHB-DEP, $p=0.3697$ for B20-DEP vs SHB-DEP).

\section{DEPs do not induce double-strand breaks in BEAS-2B and $\mathrm{A549}$ cells}

The gamma-H2AX-detectable double-strand breaks were analyzed in BEAS-2B and A549 cells cultured in the presence of 

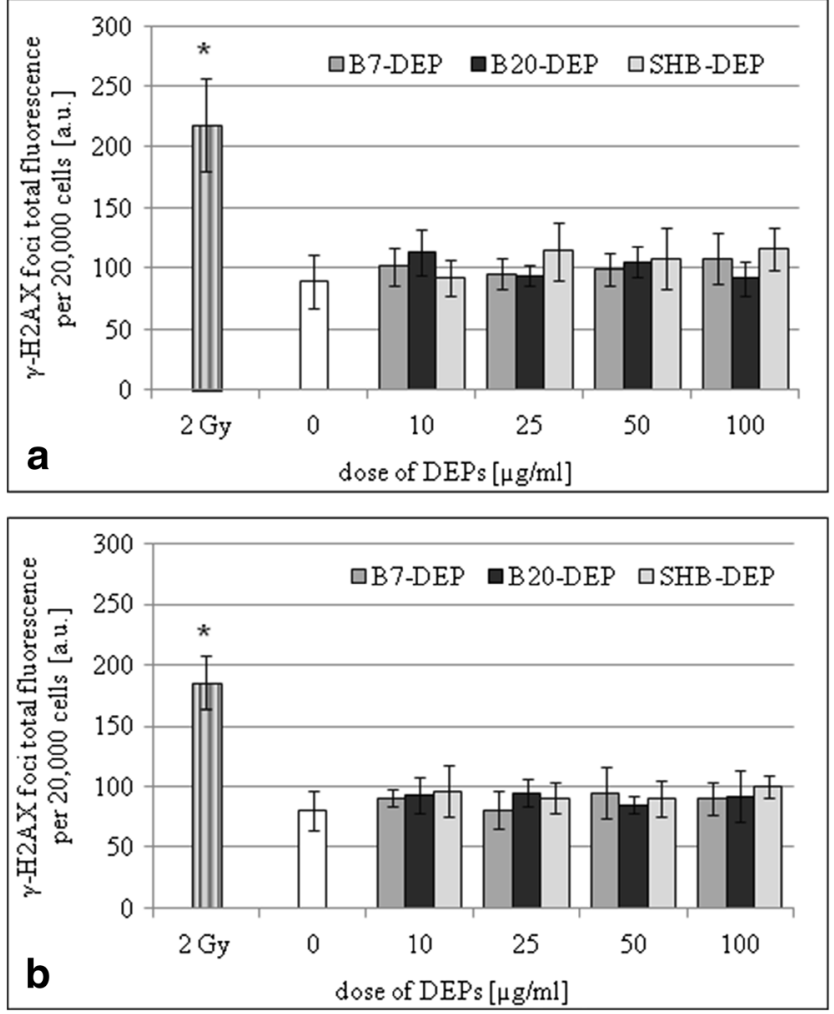

Fig. 3 Effect of DEPs (B7, B20, SHB) on induction of double-strand breaks in BEAS-2B (a) and A549 cells (b). Double-strand breaks were determined by the gamma-H2AX assay. Data are expressed as means \pm S.D. from three independent experiments. $p<0.05$. Asterisk denotes statistically significant difference versus corresponding control group

three types of DEPs $(10,25,50$, and $100 \mu \mathrm{g} / \mathrm{mL})$ for $24 \mathrm{~h}$. As presented in Fig. 3, none of the tested DEPs showed significant induction of the gamma-H2AX foci fluorescence in BEAS-2B (Fig. 3a) and A549 (Fig. 3b) cells. The positive assay control (2 Gy of ionizing radiation) significantly increased the gamma-H2AX foci fluorescence in both cell lines.

\section{DEPs induce chromosomal damage in BEAS-2B and $\mathrm{A549}$ cells}

BEAS-2B and A549 cells were cultured in the presence of three types of DEPs $(1,10$, and $50 \mu \mathrm{g} / \mathrm{mL})$ for 24 and $48 \mathrm{~h}$. The effect of DEPs on the frequency of MN in BEAS-2B cells versus corresponding control cultures is shown in Fig. 4. The increased frequency of $\mathrm{MN}$ was observed in cultures incubated with 10 and $50 \mu \mathrm{g} / \mathrm{mL}$ of B7-DEP for $24 \mathrm{~h}(p=0.0177$ and $p=0.0001$, respectively $)$ and for $48 \mathrm{~h}(p=0.0004$ and $p=0.0001$, respectively) (Fig. 4a). As presented in Fig. 4b, the increased frequency of $\mathrm{MN}$ was observed in cultures incubated with $50 \mu \mathrm{g} / \mathrm{mL}$ of B20-DEP for $24 \mathrm{~h}(p=0.0001)$ and for $48 \mathrm{~h}(p=0.0001)$. As shown in Fig. $4 \mathrm{c}$, the increased frequency of $\mathrm{MN}$ was observed in cultures incubated with $50 \mu \mathrm{g} / \mathrm{mL}$ of SHB-DEP for $24 \mathrm{~h}(p=0.0001)$ and with 10
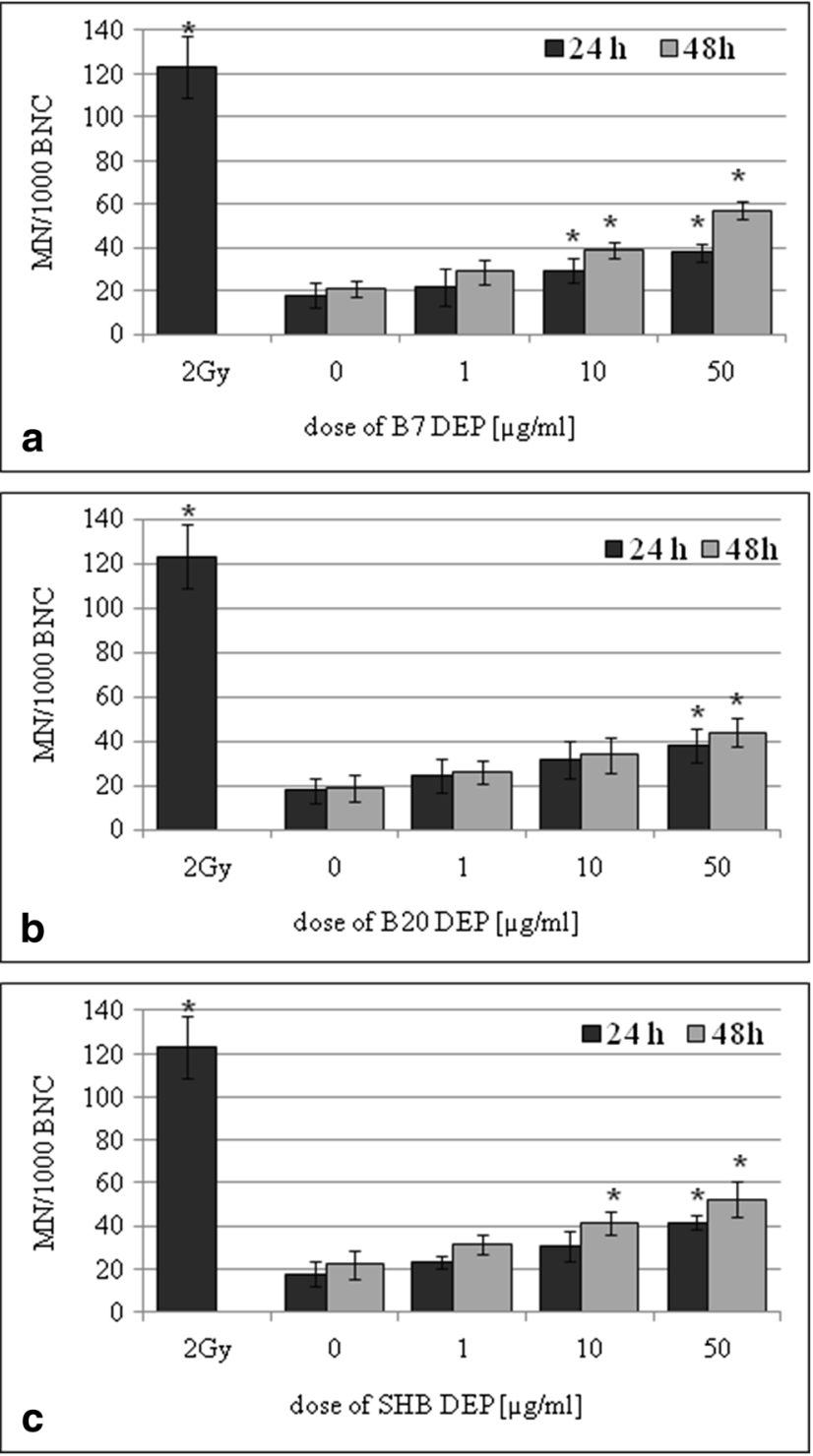

Fig. 4 Effect of DEPs on induction of micronuclei in BEAS-2B cells. The frequency of micronuclei $(\mathrm{MN})$ was determined by the micronucleus assay. a B7-derived DEPs, b B20-derived DEPs, and c SHB-derived DEPs. Data are expressed as means \pm S.D. from three independent experiments. $p<0.05$. Asterisk denotes statistically significant difference versus corresponding control group, $\mathrm{BNC}$ - binucleated cell

and $50 \mu \mathrm{g} / \mathrm{mL}$ for $48 \mathrm{~h}$ ( $p=0.0032, p=0.0016$, respectively). The effect of DEPs on the frequency of MN in A549 cells versus corresponding control cultures is shown in Fig. 5. The increased frequency of $\mathrm{MN}$ was observed in cultures incubated with $50 \mu \mathrm{g} / \mathrm{mL}$ of B7-DEP for $24 \mathrm{~h}(p=0.0016)$ and with 10 and $50 \mu \mathrm{g} / \mathrm{mL}$ for $48 \mathrm{~h}(p=0.0326$ and $p=0.0002$, respectively) (Fig. 5a). As presented in Fig. 5b, the increased frequency of $\mathrm{MN}$ was observed also in cultures incubated with $50 \mu \mathrm{g} / \mathrm{mL}$ of B20-DEP for $48 \mathrm{~h}(p=0.0032)$. As shown in Fig. $5 \mathrm{c}$, the increased frequency of $\mathrm{MN}$ was observed in cultures incubated with 10 and $50 \mu \mathrm{g} / \mathrm{mL}$ of SHB-DEP for $48 \mathrm{~h}$ 

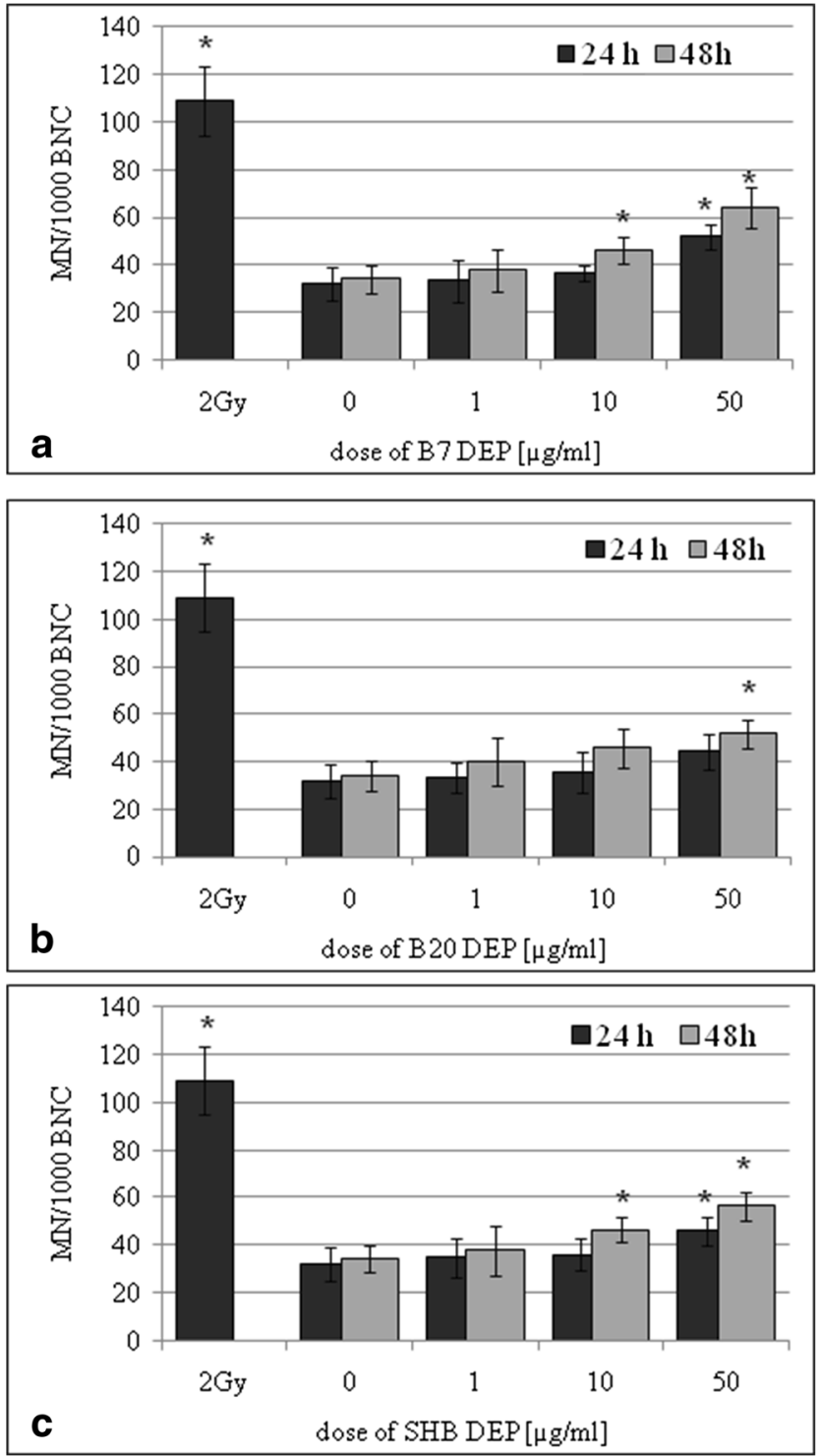

Fig. 5 Effect of DEPs on induction of micronuclei in A549 cells. The frequency of micronuclei (MN) was determined following by the micronucleus assay. a B7-derived DEPs, b B20-derived DEPs, and c SHBderived DEPs. Data are expressed as means \pm S.D. from three independent experiments. $p<0.05$. Asterisk denotes statistically significant difference versus corresponding control group, BNC — binucleated cell

( $p=0.0422$ and $p=0.0180$, respectively). However, statistical analysis revealed no significant difference in inducing micronuclei between three types of DEPs.

\section{Correlating the alkaline comet assay results with the micronucleus assay results}

Correlation of the comet assay results (\% DNA in a comet tail $24 \mathrm{~h}$ after treatment) with the micronucleus assay results (the frequency of MN in $1000 \mathrm{BNC} 24 \mathrm{~h}$ after treatment) in BEAS$2 \mathrm{~B}$ and A549 cells revealed a significant positive correlation between both endpoints. Correlation coefficients for BEAS-2B cells are as follows: for B7-DEP: $r=0.9364, p=0.0435$; for B20-DEP: $r=0.9907, p=0.0382$; and for SHB-DEP: $r=0.9831, p=0.0292$. Correlation coefficients for A549 cells are as follows: for B7-DEP: $r=0.9943, p=0.0089$; for B20DEP: $r=0.9814, p=0.0382$; and for BSHB-DEP: $r=0.9648$, $p=0.0451$.

\section{Gene expression profiling in BEAS-2B and A549 cells exposed to DEPs}

To elucidate the molecular mechanism behind the observed effects in BEAS-2B and A549 cells, we analyzed the effects of DEPs on the expression of 84 different genes involved in DNA damage signaling pathways by the real-time PCR (Supplementary Table I and Supplementary Table II). Cells were exposed to $50 \mu \mathrm{g} / \mathrm{mL}$ of DEPs for $6 \mathrm{~h}$. Experiments with BEAS-2B cells revealed that 11 genes appeared to be significantly deregulated by B7-DEP (upregulated: DDB2, ERCC1, GADD45G, and TP73; downregulated: FEN1, MDC1, PMS1, PPM1D, RAD50, RAD51B, and TP53BP1), 4 genes by B20DEP (upregulated: GADD45G and TP73; downregulated: PMS1, PPM1D), and 11 genes by SHB-DEP (upregulated: DDB2, ERCC1, GADD45G, and TP73; downregulated: FEN1, MDC1, PMS1, PPM1D, RAD50, RAD51B, and TP53BP1) (Fig. 6a). Experiments with A549 cells revealed that 6 genes were significantly deregulated by B7-DEP (upregulated: CRY1, DDB2, GADD45A, HUS1, and XRCC2; downregulated: SIR1), 4 genes by B20-DEP (upregulated: DDB2, GADD45A, and HUS1; downregulated: SIR1), and 6 genes by SHB-DEP (upregulated: CRY1, DDB2, GADD45A, HUS1, and XRCC2; downregulated: SIR1) (Fig. 6b).

\section{Discussion}

Our previous study revealed that particulate emissions from the combustion of two first-generation biofuels, 7\% FAME (B7) and 20\% FAME (B20), and a second-generation 20\% FAME/HVO (SHB) biofuel induced cytotoxic effects in BEAS-2B and A549 cells, manifested as cell death, intracellular reactive oxygen species (ROS) production, and increased expression of antioxidant genes (Lankoff et al. 2017). Since it is commonly accepted that the attack of ROS on DNA may generate a whole series of DNA damage, among them singleand/or double-strand breaks, abasic sites, base and sugar lesions, and a large number of pyrimidine- and purine-derived oxidative DNA lesions (Tudek et al. 2010), the purpose of this study was to determine the genotoxic effects of these particles in BEAS-2B and A549 cells.

Among the available genotoxicity tests, which were assessed by the IARC workgroup with the aim of describing mechanisms of carcinogenicity of air pollution particles, the comet assay (CA) is a widely acknowledged tool in molecular 


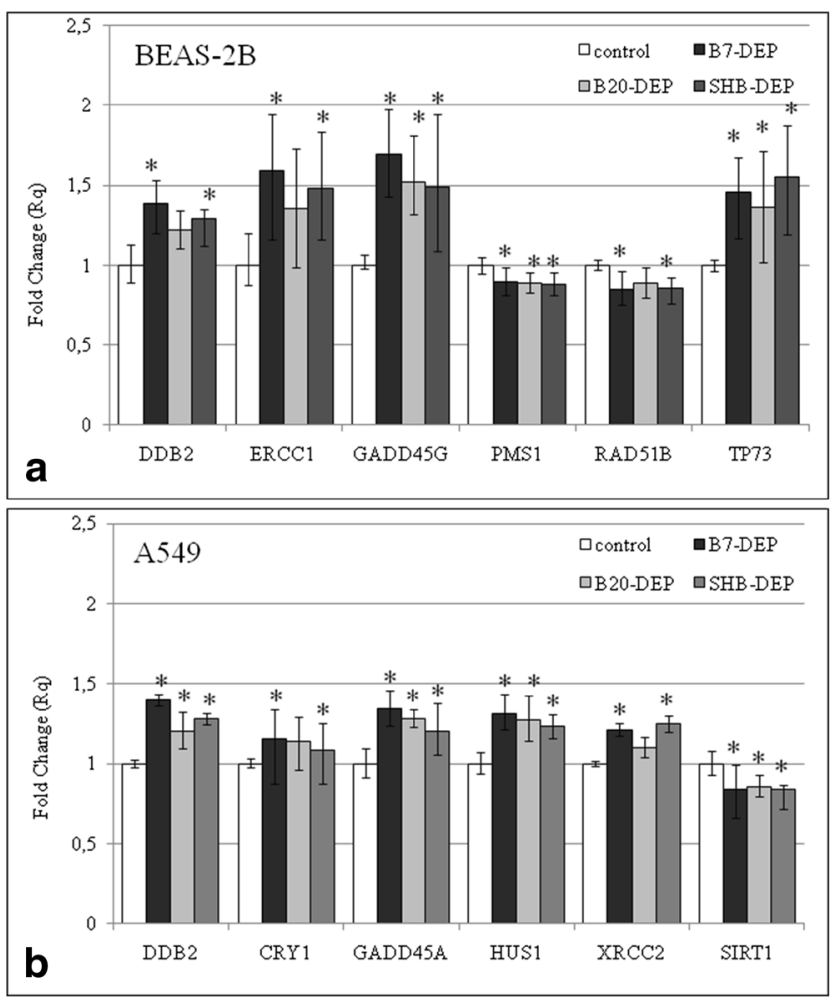

Fig. 6 Changes in gene expression in BEAS-2B cells (a) and A549 cells (b) after treatment with $50 \mu \mathrm{g} / \mathrm{mL}$ of three types of DEPs for $6 \mathrm{~h}$. Mean fold change values from three independent experiments are presented. Error bars represent minimum and maximum values in sample. Fold changes statistically significant in Student's $t$ test are highlighted (asterisk)

epidemiology and genetic toxicology (Araldi et al. 2015). We applied the alkaline comet assay, which is typically referred to as measuring "DNA SSBs" or "DNA damage." Our results revealed a dose-dependent increase in the level of SSBs in cells treated with all types of DEPs. Among the studied DEPs, B7-DEP exposure caused maximum DNA damage, while B20-DEP and SHB-DEP induced SSBs at the similar level. This is most likely due to differences in the physicochemical properties of the three types of DEP tested. A number of characteristic parameters of particles affect their toxicity, including their size, shape, surface reactivity, surface charge, surface coating, and elemental composition (Øvrevik et al. 2015). While the size, morphology, and surface charge of the three types of DEPs tested in this study were similar, the presence of organic compounds including PAH and/or nitroPAH compounds adsorbed onto the particle surface could be expected to have an impact. B7-derived DEP contained the highest concentration of PAHs. The increase in bioadditive ratio caused a decrease in the $\mathrm{PAH}$ concentration of sufficient magnitude to diminish the observed effects, as demonstrated for B20-DEPs and SHB-DEPs. The role of PAHs adsorbed on diesel soot emissions has been extensively reviewed, showing that genotoxic effects of organic extracts from combustion- generated particles are mainly connected with PAHs and their derivative (Topinka et al. 2012). Nevertheless, studies related to the associations between biodiesel-derived DEP exposures and the CA endpoints are almost completely missing. Among these reports available, Jalava et al. (2010) used the CA to determine DNA damage in the 264.7 macrophages following exposure to DEPs from the combustion of $100 \%$ diesel oil and two biodiesels (100\% HVO and 100\% RME). They found that all DEP samples induced SSBs at the same level, except weaker response for the RME sample with a catalyst. Two years later, the same group published the results showing that DEPs from the combustion of five fuels (100\% diesel, 100\% HVO, 30\% HVO, 100\% RME, 30\% RME) induced a dosedependent fragmentation of chromosomal DNA. Emission particles from the engine powered by $100 \%$ diesel and $30 \%$ HVO were the most potent inducers of SSBs (Jalava et al. 2012).

One of the commonest sources of SSBs is oxidative attack by endogenous ROS. SSBs can arise directly via disintegration of the oxidized sugar or indirectly during the DNA base excision repair (BER) of oxidized bases and abasic sites, as well as during the nucleotide excision repair (NER) of damaged or altered nucleotides. More recently, it has emerged that SSBs can also arise as a result of erroneous or abortive activity of cellular enzymes such as DNA topoisomerase 1 (Top1) or erroneous incorporation of ribonucleotides into DNA (Caldecott 2014). The alkaline CA does not distinguish between SSBs due to direct oxidative DNA damage and indirect SSBs (Collins et al. 2017). Thus, it has been of particular interest to elucidate the origin of SSBs induced by DEPs tested in our study. We therefore used the enzyme-modified CA, which enable the detection of oxidized bases by combining the assay with the use of a formamidopyrimidineDNA glycosylase (FPG) converting altered purines into DNA breaks (Collins 2014). We found that none of the tested DEPs showed significant induction of oxidative DNA base damage in BEAS-2B and A549 cells, suggesting the DNA repair-related origin of SSBs rather than oxidative stress-related. On the contrary to our findings, Hemmingsen et al. (2011) found that SSBs and FPG sensitive sites showed concentrationdependent increases in A549 cells exposed to particles from the combustion of RME-derived biofuel (B20) and pure diesel, with small differences between the B20 and B0 particles. However, along with our study, Gualtieri et al. (2011) reported that urban PM2.5 were more potent compared to PM10 for SSB generation in BEAS-2B cells, whereas there was no effect on FPG total sites. On the contrary, Jantzen et al. (2012) reported that the reference DEPs (SRM2975 and SRM1650b) generated SSBs and oxidatively damaged DNA, measured using the enzyme-modified CA on formamidopyrimidine-DNA glycosylase or oxoguanine DNA glycosylase (hOGG1)-sensitive sites in A549 and THP-1a cells, as well as in co-cultures of 
A549 and THP-1a cells. Recently, Vattanasit et al. (2014) observed the dose-dependent oxidative DNA damage in the lymphoblasts and lung cells exposed to DEPs.

Single-strand breaks can have an impact on cell fate, if they are not repaired rapidly and appropriately. The most likely consequence of the increased level of SSBs in nonproliferating cells is cell death by stalling of RNA polymerases during transcription. However, in proliferating cells, the most likely consequence is the blockage or collapse of DNA replication forks during the S phase of the cell cycle, leading to the formation of double-strand breaks (DSBs), chromosome rearrangements, and genomic instability (Woodbine et al. 2011). To elucidate whether the increased level of SSBs observed in the comet assay results in induction of DSBs, we treated BEAS-2B and A549 cells in the same manner as for the analysis of SSBs and used the $\gamma$ $\mathrm{H} 2 \mathrm{AX}$ assay, which is considered attributable to the direct formation of DSBs (Rogakou et al. 1998). Our results revealed that none of the tested DEPs showed induction of the gamma-H2AX-detectable double-strand breaks. To the best of our knowledge, a study investigating the effects of biodieselderived DEPs or their organic extracts on induction of DSBs has not been published yet, so comparable data are not available. However, Toyooka et al. (2012) determined the formation of DSBs in A549, MCF7, HaCaT, and A549 cells exposed to 9,10-phenanthrenequinone $(9,10-\mathrm{PQ})$, a major quinone in DEPs, and reported small amounts of $\gamma$-H2AX, shown as fluorescence foci.

To further elucidate whether the increased level of SSBs observed in the comet assay may be related to DNA damage at the chromosome level, we applied the micronucleus assay, a multi-target genotoxic endpoint, assessing not only clastogenic and aneugenic events but also some epigenetic effects (Kirsch-Volders et al. 2011). Our results revealed that all types of DEPs increased the frequency of micronuclei in a dose- and time-dependent manner in BEAS-2B and A549 cells when compared to controls. However, statistical analysis revealed no significant difference in inducing micronuclei between the three types of DEPs. Our results are in line with the findings of Cervena et al. (2016), who observed significantly increased frequency of MN in BEAS-2B cells exposed to extractable organic matter from particle emissions from combustion of various biodiesel fuels and pure diesels (B0, B30, B100). The genotoxicity of these extracts was comparable. On the contrary, Leme et al. (2012) studied the genotoxic mode of action of pure soybean biodiesel water extract (B100) and its blends in diesel oil (B5, B20, B50) using the flow cytometry-based MN assay. These authors reported a clear increase in the MN frequency after exposure of CHO-K1 to the B100 sample and suggested a clastogenic mode of action. Apart from the B100 sample, no other test extract showed significant $\mathrm{MN}$ induction in this test system.
Comparative analysis of genotoxicity of the three types of DEPs in BEAS-2B and A549 cells by the alkaline CA, the enzyme-modified CA, the gamma-H2AX assay, and the MN assay showed significant positive correlations between endpoints evaluated by the alkaline $\mathrm{CA}$ and the MN assay. The overall results suggest that the increased level of SSBs is likely the indicator of DNA damage induction and repair due to the presence of breaks in the lesion repair via BER or NER. To confirm our assumption, we analyzed the expression of 84 different genes involved in DNA damage signaling pathways by the real-time PCR. Supplementary Table I summarizes the differential expression of the genes tested in BEAS-2B cells. Among these genes, commonly upregulated genes were as follows: DDB2, ERCC1, TP73, and GADD45G. Elevated expression of DDB2 (damaged DNA binding protein 2) may be interpreted as response to DNA damage and repair, since this gene encodes a smaller subunit of the damaged DNA binding protein DDB, which recognizes DNA damage and is required for efficient NER, a DNA repair pathway involved in the removal of bulky DNA adducts (Forestier et al. 2015). ERCC1 (DNA excision repair protein 1) forms the ERCC1-XPF enzyme complex that participates in NER and repair of interstrand crosslinks (Formica et al. 2017). Upregulated expression of TP73 (p73) is an indicator of DNA damage as TP73 promotes a growth arrest and/or apoptosis similar to p53 (Candi et al. 2014). GADD45G (the growth arrest and DNA damage-inducible 45) protein plays an important role in cellular genotoxic and non-genotoxic stress responses including NER and cell cycle control (Hildesheim et al. 2002). In addition, downregulation of FEN1, MDC1, PMS1, PPM1D, RAD50, and TP53BP1 may suggest disturbances of DNA damage recognition and repair since FEN1 (flap endonuclease 1) removes 5' overhanging "flaps" of single-stranded DNA (Balakrishnan and Bambara 2013); MDC1 (mediator of DNA damage checkpoint protein 1) is part of the DNA damage response pathway, the mechanism through which cells respond to damaged DNA (Coster and Goldberg 2010); PPP1R15A (protein phosphatase 1 regulatory subunit $15 \mathrm{~A}$ ) responds to treatment with DNA-damaging agents; PMS1 (PMS1 protein homolog 1) is involved in DNA mismatch repair (Goellner et al. 2015); PPM1D (Protein phosphatase 1D) is a negative regulator of cell stress response pathways (Zhu and Bulavin 2012); RAD50 (DNA repair protein RAD50) is involved in DSBs repair; and TP53BP1 (tumor suppressor p53binding protein 1) plays a key role in response to DNA damage (Panier and Boulton 2014). We also identified several genes in A549 cells that were differentially expressed as compared to BEAS-2B cells (Supplementary Table II). Among these genes, 
commonly upregulated genes were as follows: HUS1 and XRCC2. Elevated expression of HUS1 (checkpoint protein HUS1) may suggest response to DNA damage since the protein encoded by this gene is a component of genotoxinactivated checkpoint complex that is involved in the cell cycle arrest in response to DNA damage (Weiss et al. 2000). XRCC2 (DNA repair protein XRCC2) is involved in the repair of DNA double-strand breaks by homologous recombination (Thacker and Zdzienicka 2004). However, SIR1 (sirtuin 1) is an intracellular regulatory protein with mono-ADP-ribosyltransferase activity (Abdellatif 2012). Taken together, these data clearly indicate that all types of DEPs deregulated expression of genes, which encode proteins playing an important role in response to DNA damage and repair in BEAS-2B and A549 cells. These proteins are mainly involved in recognition of DNA damage, cell cycle arrest in response to DNA damage, and its repair by NER, a DNA repair pathway involved in the removal of bulky DNA adducts. Therefore, the gene expression results support our assumption that the increased level of SSBs is likely the indicator of DNA repair due to the presence of breaks in the lesion repair via NER.

\section{Conclusions}

To conclude, our findings indicate that particulate engine emissions from each type of biodiesel fuel induced genotoxic effects in BEAS-2B and A549 cells, manifested either as the increased levels of single-strand breaks, the increased frequencies of micronuclei, or deregulated expression of genes involved in DNA damage signaling pathways. Our results revealed also that none of the tested DEPs caused the induction of oxidative DNA damage and the gamma-H2AX-detectable double-strand breaks. The most pronounced differences concerning the tested particles were observed for the induction of single-strand breaks, with the greatest genotoxicity being associated with the B7-derived DEPs. Differences in other effects between DEP from the different biodiesel blend percentage and biodiesel feedstock were also observed, but the magnitude of these differences were rather marginal. Overall, this suggests that increasing the concentration of FAME in biodiesel from the current 7 to $20 \%$ or substituting FAME with HVO affects the toxicity from DEP emissions, but the biological significance of this may be moderate. However, these results should be taken with some caution, since they were obtained in in vitro systems. A combination of these results with the results from in vivo genotoxicity studies, performed as part of the FuelHealth project (unpublished results), should help to better understand the toxicity induced by DEPs from the combustion of various biodiesel fuels.
Funding This work was supported by Polish-Norwegian Research Cooperation Programme, Project FuelHealth: Green fuels and human health - toxicity of engine emissions from 1 st and 2 nd generation biodiesel fuels [Pol-Nor/201040/72/2013].

Open Access This article is distributed under the terms of the Creative Commons Attribution 4.0 International License (http:// creativecommons.org/licenses/by/4.0/), which permits unrestricted use, distribution, and reproduction in any medium, provided you give appropriate credit to the original author(s) and the source, provide a link to the Creative Commons license, and indicate if changes were made.

\section{References}

Abdellatif M (2012) Sirtuins and pyridine nucleotides. Circ Res 111:642-656

André V, Barraud C, Capron D, Preterre D, Keravec V, Vendeville C, Cazier F, Pottier D, Morin JP, Sichel F (2015) Comparative mutagenicity and genotoxicity of particles and aerosols emitted by the combustion of standard vs. rapeseed methyl ester supplemented biodiesel fuels. Mut Res Gen Toxicol Environ Mut 777:33-42

Araldi RP, de Melo TC, Mendes TB, de Sá Júnior PL, Nozima BH, Ito ET, de Carvalho RF, de Souza EB, de Cassia Stocco R (2015) Using the comet and micronucleus assays for genotoxicity studies: a review. Biomed Pharmacother 72:74-82

Balakrishnan L, Bambara RA (2013) Flap endonuclease 1. Annu Rev Biochem 82:119-138

Bünger J, Krahl J, Franke H-U, Munack A, Hallier E (1998) Mutagenic and cytotoxic effects of exhaust particulate matter of biodiesel compared to fossil diesel fuel. Mut Res Gen Tox Environ Mut 415:13-23

Bünger J, Krahl J, Schröder O, Schmidt L, Westphal GA (2012) Potential hazards associated with combustion of bio-derived versus petroleum-derived diesel fuel. Crit Rev Toxicol 42:732-750

Caldecott KW (2014) DNA single-strand break rep air. Exp. Cell. Res. $32: 2-8$

Candi E, Agostini M, Melino G, Bernassola F (2014) How the TP53 family proteins TP63 and TP73 contribute to tumorigenesis: regulators and effectors. Hum Mutat 35:702-714

Cao Y, Long J, Ji Y, Chen G, Shen Y, Gong Y, Li J (2016) Foam cell formation by particulate matter (PM) exposure: a review. Inhal Toxicol 28:583-590

Cervena T, Rossnerova A, Sikorova J, Beranek V, Vojtisek-Lom M, Ciganek M, Topinka J, Rossner P Jr (2016) DNA damage potential of engine emissions measured in vitro by micronucleus test in human bronchial epithelial cells. Basic Clin Pharmacol Toxicol. https://doi.org/10.1111/bcpt.12693

Collins AR (2014) Measuring oxidative damage to DNA and its repair with the comet assay. Biochim Biophys Acta 1840:794-800

Collins A, El Yamani N, Dusinska M (2017) Sensitive detection of DNA oxidation damage induced by nanomaterials. Free Rad Biol Med 107:69-76

Coster G, Goldberg M (2010) The cellular response to DNA damage: a focus on MDC1 and its interacting proteins. Nucleus 1:166-178

Czarnocka J, Odziemkowska M (2016) Characterization of the polycyclic aromatic hydrocarbons emitted from a compression ignition engine powered with biofuels of the 1st and 2nd generation. CHEMIC 8: $419-425$

Fenech M (2007) Cytokinesis-block micronucleus cytome assay. Nat Protoc 2:1084-1104

Forestier A, Douki T, De Rosa V, Béal D, Rachidi W (2015) Combination of $A \beta$ secretion and oxidative stress in an Alzheimer-like cell line leads to the over-expression of the nucleotide excision repair proteins DDB2 and XPC. Int J Mol Sci 16:17422-17444 
Formica V, Doldo E, Antonetti FR, Nardecchia A, Ferroni P, Riondino S, Morelli C, Arkenau HT, Guadagni F, Orlandi A, Roselli M (2017) Biological and predictive role of ERCC1 polymorphisms in cancer. Crit Rev Oncol Hematol 111:133-114

Goellner EM, Putnam CD, Kolodner RD (2015) Exonuclease 1dependent and independent mismatch repair. DNA Repair (Amst) 32:24-32

Gualtieri M, Ovrevik J, Mollerup S, Asare N, Longhin E, Dahlman HJ, Camatini M, Holme JA (2011) Airborne urban particles (Milan winter-PM2.5) cause mitotic arrest and cell death: effects on DNA, mitochondria, AhR binding and spindle organization. Mutat Res 713:18-31

Hemmingsen JG, Møller P, Nøjgaard JK, Roursgaard M, Loft S (2011) Oxidative stress, genotoxicity, and vascular cell adhesion molecule expression in cells exposed to particulate matter from combustion of conventional diesel and methyl ester biodiesel blends. Environ Sci Technol 45:8545-8551

Hesterberg TW, Long CM, Bunn WB, Lapin CA, McClellan RO, Valberg PA (2012) Health effects research and regulation of diesel exhaust: an historical overview focused on lung cancer risk. Inhal Toxicol 1:1-45

Hildesheim J, Bulavin DV, Anver MR, Alvord WG, Hollander MC, Vardanian L (2002) Gadd45a protects against UV irradiationinduced skin tumors, and promotes apoptosis and stress signaling via MAPK and p53. Cancer Res 62:7305-7315

Jalava PI, Tapanainen M, Kuuspalo K, Markkanen A, Hakulinen P, Happo MS, Pennanen AS, Ihalainen M, Yli-Pirilä P, Makkonen U, Teinilä K, Mäki-Paakkanen J, Salonen RO, Jokiniemi J, Hirvonen MR (2010) Toxicological effects of emission particles from fossiland biodiesel-fueled diesel engine with and without DOC/POC catalytic converter. Inhal Toxicol 2:48-58

Jalava PI, Aakko-Saksa P, Murtonen T, Happo MS, Markkanen A, YliPirilä P, Hakulinen P, Hillamo R, Mäki-Paakkanen J, Salonen RO, Jokiniemi J, Hirvonen MR (2012) Toxicological properties of emission particles from heavy duty engines powered by conventional and bio-based diesel fuels and compressed natural gas. Part Fibre Toxicol 9:37

Jantzen K, Roursgaard M, Desler C, Loft S, Rasmussen LJ, Møller P (2012) Oxidative damage to DNA by diesel exhaust particle exposure in co-cultures of human lung epithelial cells and macrophages. Mutagenesis 27:693-701

Kirsch-Volders M, Plas G, Elhajouji A, Lukamowicz M, Gonzalez L, Vande Loock K, Decordier I (2011) The in vitro MN assay in 2011: origin and fate, biological significance, protocols, high throughput methodologies and toxicological relevance. Arch Toxicol 85:873-899

Krahl J, Munack A, Ruschel Y, Schröder O, Bünger J (2008) Exhaust gas emissions and mutagenic effects of diesel fuel, biodiesel and biodiesel blends. SAE Technical Paper. 2008-01-2508

Kruszewski M, Wojewódzka M, Iwaneńko T, Collins AR, Szumiel I (1998) Application of the comet assay for monitoring DNA damage in workers exposed to chronic low-dose irradiation. II Base damage Mutation Res 416:37-57

Lankoff A, Brzoska K, Czarnocka J, Kowalska M, Lisowska H, Mruk R, Øvrevik J, Wegierek-Ciuk A, Zuberek M, Kruszewski M (2017) A comparative analysis of in vitro toxicity of diesel exhaust particles from combustion of 1 st- and 2 nd-generation biodiesel fuels in relation to their physicochemical properties-the FuelHealth project. Environ Sci Pollut Res Int. https://doi.org/10.1007/s11356-0179561-9

Leme DM, Grummt T, Heinze R, Sehr A, Renz S, Reinel S, de Oliveira DP, Ferraz ER, de Marchi MR, Machado MC, Zocolo GJ, MarinMorales MA (2012) An overview of biodiesel soil pollution: data based on cytotoxicity and genotoxicity assessments. J Hazard Mater 199-200:343-349

Øvrevik J, Refsnes M, Låg M, Holme JA, Schwarze PE (2015) Activation of proinflammatory responses in cells of the airway mucosa by particulate matter: oxidant- and non-oxidant-mediated triggering mechanisms. Biomol Ther 5:1399-1440

Panier S, Boulton SJ (2014) Double-strand break repair: 53BP1 comes into focus. Nat Rev Mol Cell Biol 15:7-18

Rantanen L, Linnaila R, Aakko P, Harju T (2005) NExBTL - Biodiesel Fuel of the Second Generation. SAE Technical Paper 2005-01-3771. https://doi.org/10.4271/2005-01-3771

Rogakou EP, Pilch DR, Orr AH, Ivanova VS, Bonner WM (1998) DNA Double-stranded Breaks Induce Histone H2AX Phosphorylation on Serine 139. J Biol Chem 273:5858-5868

Ross JA, Nelson GB, Mutlu E, Warren SH, Gilmour MI, DeMarini DM (2015) DNA adducts induced by activation of extracts of diesel and biodiesel exhaust particles. Inhal Toxicol 27:576-584

Steiner S, Bisig C, Petri-Fink A, Rothen-Rutishauser B (2016) Diesel exhaust: current knowledge of adverse effects and underlying cellular mechanisms. Arch Toxicol 90:1541-1553

Thacker J, Zdzienicka MZ (2004) The XRCC genes: expanding roles in DNA double-strand break repair. DNA Repair (Amst) 8-9:1081-1090

Topinka J, Milcova A, Schmuczerova J, Mazac M, Pechout M, VojtisekLom M (2012) Genotoxic potential of organic extracts from particle emissions of diesel and rapeseed oil powered engines. Toxicol Lett $1: 11-17$

Toyooka T, Shinmen T, Aarts JM, Ibuki Y (2012) Dual effects of Nacetyl-L-cysteine dependent on NQO1 activity: suppressive or promotive of 9,10-phenanthrenequinone-induced toxicity. Tox ApplPharmacol 3:404-412

Tudek B, Winczura A, Janik J, Siomek A, Foksinski M, Oliński R (2010) Involvement of oxidatively damaged DNA and repair in cancer development and aging. Am J Transl Res 3:254-284

Vattanasit U, Navasumrit P, Khadka MB, Kanitwithayanun J, Promvijit J, Autrup H, Ruchirawat M (2014) Oxidative DNA damage and inflammatory responses in cultured human cells and in humans exposed to traffic-related particles. Int J Hyg Environ Health 217:23-33

Vieira JL, Macedo FY, Benjo AM, Guimarães GV, Contreras JP, Bocchi EA (2017) Systemic effects of controlled exposure to diesel exhaust: a meta-analysis from randomized controlled trials. Ann Med 49: $165-175$.

Weiss RS, Leder P, Enoch T (2000) A conserved role for the Hus1 checkpoint protein in eukaryotic genome maintenance. Cold Spring Harb Symp Quant Biol 65:457-466

Westerholm R, Christensen A, Törnqvist M, Ehrenberg L, Rannug U, Sjögren M, Rafter J, Soontjens C, Almén J, Grägg K (2001) Comparison of exhaust emissions from Swedish environmental classified diesel fuel (MK1) and European Program on Emissions, Fuels and Engine Technologies (EPEFE) reference fuel: a chemical and biological characterization, with viewpoints on cancer risk. Environ. Sci. Technol. 9:1748-1754

Westphal GA, Krahl J, Munack A, Ruschel Y, Schröder O, Hallier E, Brüning T, Bünger J (2012) Mutagenicity of diesel engine exhaust is eliminated in the gas phase by an oxidation catalyst but only slightly reduced in the particle phase. Environ. Sci. Technol. 11: 6417-6424

Wojewódzka M, Kruszewski M, Iwaneńko T, Collins AR, Szumiel I (1998) Application of the comet assay for monitoring DNA damage in workers exposed to chronic low-dose irradiation. I Strand breakage Mutat Res 416:21-35

Woodbine L, Brunton H, Goodarzi AA, Shibata A, Jeggo PA (2011) Endogenously induced DNA double strand breaks arise in heterochromatic DNA regions and require ataxia telangiectasia mutated and Artemis for their repair. Nucleic Acids Res 39:6986-6997

Zhu YH, Bulavin DV (2012) Wip1-dependent signaling pathways in health and diseases. Prog Mol Biol Transl Sci Prog Mol Biol Transl Sci 106:307-325 